\title{
Estrutura social da sociedade russa contemporânea
}

\author{
TATIANA I.ZASLÁVSKAIA
}

\author{
Tarefas e métodos da pesquisa
}

C

OLOCAÇÃO DO PROBLEMA - A transformação institucional da sociedade russa, ocorrida nos últimos anos, teve sérios reflexos na sua estrutura social. Mudaram e continuam a mudar as relações de propriedade e poder, reestruturam-se os mecanismos de estratificação social, e ocorre uma intensa mudança das elites. No cenário social, surgem novos grupos sociais, camadas de massa são marginalizadas, amplia-se o fosso social. As relações econômicas criminalizam-se cada vez mais. Em conseqüência, muda o sistema de interesses, de métodos de comportamento e de interações sociais dos diversos grupos. Esses fenômenos, que à primeira vista parecem isolados um do outro, representam na realidade facetas diferentes do processo de transformação da sociedade. Por isso, é importante estudá-los, não apenas em particular, mas também em sua interligação. A tarefa fundamental dos cientistas sociais é a descrição da sociedade russa como um sistema social integrado, que se encontra em transformação, antes de mais nada, por influência de forças motrizes internas. As características mais importantes desse sistema são, em primeiro lugar, a estrutura social, isto é, a composição, a posição e as relações dos grupos determinadores do seu desenvolvimento, e, em segundo, a estratificação da sociedade, ou a distribuição dos grupos mencionados na escala hierárquica dos status sociais.

Como critérios básicos de status dos grupos sociais e, correspondentemente, também da estratificação da sociedade, costuma-se considerar: o potencial politico, expresso pelo volume de funções de poder e de direção; o potencial econômico, que se manifesta na dimensão da propriedade e dos rendimentos e no nível de vida; o potencial sócio-cultural, que reflete o nível de escolaridade, qualificação e profissionalismo dos trabalhadores, as particularidades do modo e da qualidade de vida; e, finalmente, o prestígio social, que constitui um reflexo concentrado das características citadas. Todos esses critérios estão de certo modo inter-ligados, mas, ao mesmo tempo, formam "eixos" relativamente independentes do espectro da estratificação. Os conceitos de potencial político (de direção), econômico e sócio-cultural dos grupos são aplicáveis à maioria das sociedades contemporâneas, mas o seu conteúdo social concreto e a sua "contribuição" relativa para a formação dos status dos grupos, são específicos em cada uma delas.

A Rússia encontra-se em transição do pós-totalitarismo para o pluralismo político e a democracia, e da economia administrativo-distributiva estatizada para 
a economia privada de mercado. Em conformidade com isso, os critérios de estratificação social têm caráter transitório e seus processos de mudança são bastante complexos, porquanto a destruição das relações sociais antigas é mais rápida do que a formação de novas. Para se compreender as mudanças ocorridas nesse campo é útil comparar os traços principais da estratificação da sociedade russa atual e os da anterior à perestroika, com a qual teve início o processo de transformação.

$\mathrm{Na}$ estratificação da sociedade soviética, o papel decisivo cabia ao capital político, definido pelo lugar ocupado pelos grupos sociais na hierarquia estatalpartidária. O lugar dos indivíduos e dos grupos no sistema de poder e de direção predeterminava não somente o volume dos direitos sob seu comando e o nível da tomada de decisões, mas também o seu círculo de relações sociais e a dimensão das suas possibilidades informais. A estabilidade do sistema político assegurava a da composição e da posição da elite política - a nomenklatura -, bem como o seu distanciamento e o seu isolamento dos grupos por ela comandados.

A situação atual caracteriza-se pelo enfraquecimento acentuado do poder estatal. A tensa luta dos partidos e grupelhos políticos, a elaboração inacabada de seus programas construtivos, a perda da confiança do povo na maioria das instituições políticas e a propagação jamais vista da ilegalidade e da corrupção, determinam a rápida substituição dos políticos e a instabilidade do sistema político como um todo. A estratificação da camada dirigente segundo o princípio da nomenklatura, ocorrida na era soviética, acha-se em "estado de semi-desintegração", isto é, o seu arcabouço ainda se mantém, mas o seu mecanismo de reprodução está destruído. O sistema dos órgãos de poder foi substancialmente reestruturado; alguns foram liquidados, outros apenas organizados e terceiros mudaram radicalmente as suas funções. Em conseqüência, possuímos hoje, formalmente, um novo sistema de cargos superiores de administração pública. Renovou-se também o quadro de pessoas que ocupam tais cargos, parte das quais transferida de outras esferas de atividades. Com isso, a camada superior antes fechada da sociedade entreabriu-se para pessoas oriundas de outros grupos. À primeira vista, a antiga nomenklatura desapareceu, dissolvida em outras camadas da sociedade. Na realidade, porém, ela perdura. Continua a existir esmagadora parcela tanto dos cargos anteriores à nomenklatura como das funções de poder e comando a eles relacionadas. Além disso, mais da metade dos cargos semiassociados à nomenklatura está ocupada pela antiga elite política, que utiliza modelos de gestão característicos do sistema soviético. Entre os membros da antiga nomenklatura mantêm-se relações de trabalho estáveis, que asseguram a manutenção das consciências corporativa e de classe própria a ela (1).

Ao mesmo tempo, a desestabilização do poder e a "temporariedade" dos governantes propiciam um relativo enfraquecimento do papel do componente político da estratificação social. É claro que a dimensão dos mandatos de poder e políticos tem grande efeito sobre a formação do status social do grupo. No entanto, o papel principal cabe, se assim se pode dizer, ao fator "econômico-político", isto é, ao lugar que ocupam os grupos sociais na gestão da economia, na 
privatização da propriedade social e na disposição dos recursos materiais e financeiros. A redistribuição da riqueza acumulada é quase a única esfera da atividade de gestão em que se fortaleceu o papel do poder político. A participação direta ou indireta na redistribuição da propriedade estatal constitui, na Rússia contemporânea, o mais importante fator de determinação do status social dos grupos dirigentes.

O potencial econômico dos vários grupos sociais era dado na URSS pela medida da sua participação no domínio, distribuição e utilização da riqueza social. Por esse critério, distinguiam-se grupos como a burocracia, que distribuía os bens sociais escassos; os diretores de empresas, que dispunham dos recursos financeiros e da produção delas e que comunente eram membros da economia subterrânea; os trabalhadores vinculados ao aprovisionamento técnico-material, aos comércios atacadista e varejista, à esfera de serviços à população e assim por diante. Entretanto, as pessoas que de um modo ou de outro participavam dos processos de distribuição e troca, compunham uma parcela comparativamente pequena da população. As grandes massas da sociedade não possuíam tais direitos - a sua estratificação social era determinada pelo nível dos salários e das rendas familiares, dependentes de muitos fatores, começando pelo caráter e conteúdo do trabalho, esferas e setores em que era aplicado e órgão superior ao qual estava vinculada a empresa, terminando no número de membros e na composição da família. A interação dos fatores econômicos, sociais, regionais e demográficos, entre outros, produzia um quadro bastante variado da estratificação econômica da população.

Atualmente, o potencial econômico dos grupos sociais compreende três componentes:

- domínio de capital, produtor de renda;

- participação nos processos de distribuição, deslocamento e troca do produto social;

- nível de renda e do consumo pessoais.

Estão se formando ativamente variadas formas de propriedade não-estatal, inclusive privada (individual, grupal, cooperativa, acionária, corporativa e outras), surgem diferentes tipos de capital (financeiro, comercial, industrial). No plano social, mais ou menos nitidamente, distinguem-se os possuidores de capital privado. Entre eles, há os muito grandes, os médios e os pequenos, pertencentes conseqüentemente a diferentes camadas. Importante lugar é ocupado pelos camponeses, que possuem uma exploração individual e se tornaram proprietários da terra. No entanto, a imensa maioria dos russos não possui qualquer propriedade produtiva.

O segundo dos componentes do potencial econômico citados, que antes foi dominante, agora cede a sua posição ao primeiro. Isso está relacionado com o fato de o status econômico do proprietário médio ser mais elevado do que o 
do gerente qualificado. Além disso, à medida que se privatiza a economia, os recursos materiais e financeiros passam a ter donos interessados, o que diminui a possibilidade de sua dilapidação. No entanto, o processo de saneamento da economia avança apenas como uma tendência, pois, na confusão vigente, a proximidade do "bolo social" (isto é, dos recursos estatais) desempenha um papel maior do que em qualquer outra época. Infelizmente, operacionalizar o critério dado, ou seja, medir o grau de participação dos vários grupos econômicos, profissionais e funcionais nos mecanismos de distribuição não é fácil. Mais provavelmente, de acordo com essa característica, distinguem-se os mesmos grupos sociais anteriormente existentes: diretores de empresas estatais e mistas, inclusive sociedades anônimas; trabalhadores responsáveis e especialistas do comércio; empregados do serviço de provisionamento material e técnico; ainda profissionais da área de negócios, como comerciantes, corretores entre outros.

O número de russos não possuidores de capital próprio e sem acesso à distribuição dos bens estatais diminuiu um pouco nos últimos anos. Mas eles, como antes, constituem a grande massa da sociedade. O potencial econômico dessas pessoas é determinado pelo nível das rendas derivadas do trabalho assalariado. As grandes mudanças na sua situação consistem, em primeiro lugar, na polarização muito mais acentuada do que antes da quantidade de bens por elas possuídos; e, em segundo, no quase completo desaparecimento da relação entre o trabalho e a renda.

O surgimento de uma economia multissetorial, o rechaço da regulação governamental dos salários, a falta de um mercado nacional de trabalho, o grande número de focos localizados de desemprego e, recentemente, o atraso de muitos meses no pagamento dos salários por trabalho já realizado, levaram a esfera da renda a uma situação caótica. Com isso, significativa parte da população viu-se lançada abaixo da linha da pobreza e, até, ao limiar da miséria.

Quanto ao potencial sócio-cultural, este desempenhou um papel especialmente subalterno na sociedade soviética. Pesquisas internacionais revelaram que, em relação a outros países, a interdependência dos status cultural, político e econômico dos russos era de uma fraqueza única (2). A cúpula da camada dirigente da URSS era representada por pessoas não-suficientemente instruídas e, além disso, de espírito hostil à cultura. $\mathrm{O}$ trabalho dos operários era mais bem pago do que o dos especialistas de perfil humanitário. Os dons criativos da personalidade eram mais perseguidos que incentivados. É verdade que o nível cultural, a instrução e os interesses espirituais se refletiam no modo de vida da inteligentsia e, por meio dele, no seu prestígio social. Ainda assim, o potencial cultural estratificou a sociedade, não em toda a sua extensão mas, primordialmente, as camadas com status político e econômico menos elevado. Dessa forma, trabalhadores qualificados e pessoal de nível técnico superior ocupavam uma posição superior à dos trabalhadores com menor instrução e sem profissão.

A intensa desintegração das velhas instituições sociais, característica da atualidade, conjugada à formação de outras novas, aumenta a mobilidade do trabalho 
e social. Por esse motivo, cresce sensivelmente o papel das qualidades pessoais, como dom e talento, nível de socialização, qualidade da instrução, competência, capacidade de adquirir novos conhecimentos, horizonte cultural etc. Eleva-se o valor do profissionalismo, e, portanto, o papel do capital sócio-cultural. Mas isso também é apenas uma tendência, porquanto a mobilidade social ascendente é propiciada, em igual medida, por qualidades pouco relacionadas com o potencial cultural, como juventude, energia, vontade, ambição, capacidade de organização, disposição de correr riscos, força física, agressividade, escrupulosidade moral e outras. Além disso, a sociedade russa exige apenas a parte do potencial cultural, que pode ser utilizada "aqui e agora". Daí a relativamente grande demanda por engenheiros, médicos e professores qualificados e experientes, paralelamente a uma crescente diminuição da demanda por cientistas, trabalhadores da cultura e das artes e especialistas em humanidades.

A nosso ver, existem hoje na Rússia dois sistemas de avaliação social do potencial sócio-cultural dos trabalhadores relativamente independentes um do outro. O primeiro funciona no setor não-estatal, que tem necessidade de especialistas qualificados e está disposto a renumerar bem o seu trabalho. O segundo, que se mantém tradicionalmente no setor estatal, traz, como antes, a marca do igualitarismo e da postura "niilista" em relação ao trabalho intelectual. O resultado é a divisão da inteligentsia russa em estratos, que se diferenciam substancialmente pela sua situação. Tais são, por exemplo: especialistas de perfil administrativo e econômico-jurídico qualificados e muito bem pagos, ocupados no setor privado; especialistas de perfil técnico-científico ocupados no complexo energético e em outros ramos de exportação, que conseguem se manter "à tona"; e especialistas de perfil social e humanitário, que atuam em setores mantidos pelo orçamento estatal, entregues à sua própria sorte.

No conjunto, a estrutura da sociedade russa sofreu mudanças consideráveis quando comparada à era soviética; mas, apesar disso, mantém muitos dos seus traços antigos. Para a sua transformação substancial é necessária uma reestruturação sistêmica das instituições de propriedade e poder, a qual demandará muitos anos. Entrementes, a estratificação da sociedade continuará a perder rigidez e unicidade de sentido. Os limites entre os grupos e camadas tenderão a "erodir-se", com o surgimento de muitos grupos marginais de status indefinido ou contraditório.

À primeira vista, tal tendência lembra a erosão da estrutura social de classes, observada nas sociedades ocidentais contemporâneas, mas, em nossa opinião, essa semelhança é formal. O surgimento das "sociedades de classe média", relativamente homogêneas, é característico do estágio pós-industrial do desenvolvimento. A Rússia, entretanto, não somente não ultrapassou o estágio industrial de desenvolvimento, como também está atravessando uma crise gravíssima, que faz a sua economia regredir significativamente.

Nessas condições, as distinções sociais de classe na situação dos grupos sociais, nas proporcões da propriedade privada, no grau de participação na direção da economia, no volume de bens apropriados e consumidos adquirem espe- 
cial significado. Elas ressaltam-se de forma mais aguda do que antes e determinam em muito os outros lados do status social.

Tarefas e hipóteses científicas - Pesquisas dos últimos anos assentaram as bases do estudo objetivo da estrutura da sociedade; mas a ciência russa não dispõe ainda de conhecimento sólido dela. À análise de alguns aspectos da estrutura foram dedicados centenas de trabalhos, mas a maioria deles ou limitaram-se à análise teórica do problema ou estudaram grupos sociais isolados, embora muito importantes, desvinculados do todo mais amplo. Na literatura científica estão amplamente descritos os retratos sociais de grupos e camadas, que ocupam lugares importantes na hierarquia social. Análise particularmente atenta tem sido dedicada aos grupos surgidos recentemente, que se desenvolvem intensamente e são socialmente ativos, pertencentes à chamada "camada média" (em primeiro lugar, os empresários), assim como às elites nacional e regional (3).

Nos grandes centros de estudos sociológicos, acumulam-se dados sobre a estrutura social da população de diferentes regiões da Rússia e de outros países da antiga União Soviética,como também da Europa Central e Oriental (4); no entanto, para a análise aprofundada desses dados, não raramente, faltam força e possibilidades. O aspecto dinâmico das pesquisas das estruturas sociais freqüentemente limitam-se à análise das variações do tamanho e da composição dos grupos sociais. Menos estudadas ainda são as relações e as interações entre os grupos sociais, que refletem o caráter sistêmico da estrutura social e revelam os mecanismos profundos de funcionamento e desenvolvimento da sociedade. A maioria das pesquisas da estrutura social, por ora, têm mais a ver com a "anatomia" do que com a "fisiologia" da sociedade. Por isso, o seu objeto revela-se destituído de vida interna e mecanismos de autodesenvolvimento.

O objetivo de nossa pesquisa é estudar a estrutura da sociedade russa, entendida como um sistema de grupos e camadas, cujas atividade e interação constituem a base do mecanismo social de transformação da sociedade russa. Alguns desses grupos são "atores" (iniciadores, organizadores) das reformas; a atividade de outros consiste na escolha de estratégias pessoais de adaptação às mudanças, enquanto terceiros, com mais probabilidade se tornam vítimas dos processos em curso e são incapazes de neles influir até minimamente. As tarefas gerais do nosso projeto consistem em:

- identificar os grupos sociais que influem ou são capazes de influir substancialmente no curso do processo de transformação na Rússia;

- esclarecer as particularidades da estratificação da sociedade russa contemporânea, a importância relativa dos seus critérios e os rumos das mudanças ocorridas nesse campo;

- apreender os interesses, as orientações, as opiniões e os métodos de atuação dos grupos, "atores", "participantes naturais" ou "vítimas passivas" do processo de transformação; 
- analisar o sistema de relações sociais, que ligam esses grupos entre si, e os modos de suas interações;

- com base em tudo isso, fazer um esboço de descrição do mecanismo social geral de transformação da sociedade russa (5).

Representações contemporâneas dos fatores, critérios e regularidades da estratificação da sociedade russa permitem distinguir camadas e grupos que, por hipótese, se diferenciam tanto pelo seu status social como pelo seu lugar no processo de transformação. Conforme nossa hipótese, a sociedade russa compõe-se de quatro camadas sociais: superior, média, básica e inferior, além de mais uma formada pelos excluídos.

Por camada superior entendemos sobretudo a camada realmente dirigente, que desempenha o papel de sujeito principal das reformas. A ela pertencem os grupos de elite e subelite, que ocupam as posições mais importantes no sistema da administração estatal e nas estruturas econômicas e de coerção. Os diferentes grupos da elite e da semi-elite, que formam essa camada, não raramente possuem interesses diferentes e não perseguem os mesmos objetivos. Une-os porém o fato de estarem no poder e a possibilidade de exercerem influência direta sobre o processo de transformação, principalmente nos seus aspectos, que se iniciam com reformas "de cima".

Chamamos média à segunda camada, em primeiro lugar, por sua situação na escala social e, em segundo, por ela constituir o embrião de uma camada média na compreensão ocidental do termo. É verdade que a maioria dos seus representantes não possui capital algum que lhe assegure a independência pessoal, qualquer nível de profissionalismo que atenda às exigências da sociedade pósindustrial, nem alto prestígio social. Além disso, tal camada é, por ora, muito reduzida para ser garantia da estabilidade social. Assim, uma camada média genuína só poderá se formar na Rússia a partir dos grupos sociais que hoje constituem a proto-camada correspondente. Eles são os pequenos empresários, semiempresários, os gerentes de empresas médias e pequenas, o segmento médio da burocracia, os oficiais superiores das Forças Armadas, os especialistas e os operários mais qualificados e aptos. O papel desempenhado pela camada média no processo de transformação é determinado pelo seu alto potencial de qualificação profissional em termos de Rússia, pela capacidade de adaptar-se a condições mutantes, pela ativa participação na transformação das instituições sociais arcaicas, pela situação material relativamente boa e pelo interesse na continuação das reformas. Atualmente, essa camada, não obstante a sua pouca força, constitui também o apoio social e a principal força motriz das reformas, que se realizam fundamentalmente por seus esforços. Se a camada superior encarna os desígnios e a vontade da sociedade, a camada média é a portadora da energia e da massiva atividade sócio-transformadora cotidiana.

A camada social por nós designada de básica é muito grande, abrangendo mais de dois terços de toda a sociedade. Os seus representantes apresentam um 
potencial médio de qualificação profissional e um potencial relativamente limitado de trabalho. Os principais esforços dessa camada são dirigidos não à transformação da realidade de acordo com o seu próprio interesse, mas à adaptação às mudanças que se realizam por iniciativa de outrem, freqüentemente, à busca de meios de sobrevivência. Não obstante, as formas e os modos do comportamento de adaptação dessa camada exercem grande influência sobre o curso dos processos de transformação. Em alguns casos, ela pode freá-los; em outros, acelerá-los; em terceiro, mudar a orientação social das mudanças institucionais em relação ao que foi projetado pela "cúpula". Pertencem à camada básica a parcela principal da inteligentsia (especialistas), a semi-inteligentsia (ajudantes de especialistas), os servidores pertencentes ao corpo técnico, os trabalhadores das inúmeras profissões do comércio e dos serviços, e grande parte do campesinato. Embora o status social, a mentalidade, os interesses e o comportamento desses grupos sejam diferentes, o seu papel no processo das transformações é muito semelhante. Este consiste, em primeiro lugar, em adaptar-se às condições mutantes buscando sobreviver, manter o status conseguido na medida do possível, ajudar os parentes próximos e deixar os filhos em condições de enfrentar a vida. A impossibilidade de alcançar tão importantes objetivos de vida mobiliza essa camada para a expressão de protesto social massivo, incluindo formas as mais agressivas.

A estrutura e as funções da camada inferior, que limita com a parte básica e socializada da sociedade, são menos claras. No quadro do processo contemporâneo de transformações, essa camada comparece muito mais como vítima do que como participante ativa das inovações. Os traços distintivos dos seus representantes são o baixo potencial de atividade e a incapacidade de adaptar-se às duras condições sócio-econômicas do período de transição. Tal camada é constituída • fundamentalmente ou de pessoas idosas, pouco instruídas, fracas e doentes, que recebem aposentadoria insuficiente, ou daquelas que não têm profissão e, não raramente, nem ocupação permanente, de desempregados e de refugiados ou imigrantes involuntários de regiões de conflitos de nacionalidades. É possível identificar empiricamente essa camada por características como a baixíssima renda familiar e pessoal, a pouca instrução, a ocupação em trabalho não-qualificado ou a falta de trabalho permanente. A dinâmica do tamanho e da composição da camada inferior pode constituir indicador importante dos resultados sociais das reformas.

No que concerne aos excluídos sociais ou, o que é a mesma coisa, à "subclasse", a sua principal característica, a nosso ver, é o isolamento das instituições da grande sociedade, compensado por sua inclusão em instituições criminosas ou semicriminosas específicas. Daí a limitação das relações sociais predominantemente à própria camada, a dessocialização e a perda dos hábitos de uma vida social legítima. Os representantes da subclasse social são os criminosos e os elementos semicriminosos: ladrões, bandidos, traficantes de drogas, donos de antros, grandes e pequenos vigaristas, homicidas de aluguel, bem como pessoas degeneradas, como alcoólatras, narcômanos, prostitutas, vagabundos, moradores de rua entre outros. Parte significativa dessa camada conheceu já o cárcere e 
a restante corre o perigo de conhecê-lo. A subclasse social encontra-se muito perto da camada inferior da grande sociedade. A diferença entre elas não está nas características exteriores do status social, mas no grau de legitimidade da atividade e do modo de vida e no tipo de identificação subjetiva, isto é, na consideração de si próprio como membro da grande sociedade ou da subclasse.

As dimensões e a atividade da subclasse influem seriamente no funcionamento e desenvolvimento da grande sociedade, particularmente no processo de transformação. A criminalidade é o principal canal dessa influência. As reformas de mercado, realizadas à custa da população e geradoras de seu empobrecimento massivo, acarretaram, no início, uma ampliação significativa da camada inferior, constituída de "pobres honestos"; e, em seguida, o crescimento acelerado da subclasse social criminogênica, que assimilou ativamente a parcela lumpenizada dos pobres, em especial os representantes da geração mais jovem. O resultado foi a onda impressionante de criminalidade que afetou não somente as camadas inferiores, mas toda a sociedade. A desordem jurídica que impera no país seria impossível sem o funcionamento de uma subclasse social poderosa, com os seus gangsters, bandidos, matadores de aluguel, assaltantes, extorquidores entre outros. Desse modo, a subclasse constitui importante elemento da sociedade russa e exige um estudo tão sério como o das camadas restantes.

\section{Estrutura sócio-grupal da sociedade}

Base de informações e métodos de identificação dos grupos-O objeto empírico da nossa pesquisa é a sociedade russa, e o conjunto geral estudado constitui a população trabalhadora adulta da Rússia. A base de informações do trabalho é constituída por dados do Monitoramento das mudanças econômicas e sociais na Rússia, realizado pelo Centro Russo de Pesquisa da Opinião Pública (CRPOP) desde março de 1993. Algumas particularidades preciosas desses dados são: a alta representatividade, assegurada pela presença de um número significativo de conglomerados análogos, obtidos em amostras independentes; a possibilidade de estudar grupos compostos de pequenas porções dessas amostras; a atualidade e a permanente renovação dos dados; a presença, no questionário, de uma quantidade suficiente de variáveis formadoras do status; a inclusão das várias regiões do país e de diversos tipos de cidades e zonas rurais.

Para a identificação empírica dos grupos correspondentes à hipótese inicial (6), utilizaram-se as seguintes variáveis de status: grau de instrução, autoavaliação da qualificação, ocupação principal, gênero principal de atividade, ramo de ocupação, setor da economia por forma de propriedade, tamanho da empresa (organização ou firma), grupo de cargo profissional (de acordo com o conteúdo do trabalho executado e por avaliação dos próprios entrevistados) e o nível de renda real familiar e pessoal (7). A identificação dos grupos foi feita pelo método iterativo. No primeiro passo, cada grupo foi classificado por traços fundamentados teoricamente. Em seguida, construíu-se o "retrato" do status desse grupo, a partir de um conjunto de variáveis que permitiram verificar se realmente todos 
os entrevistados classificados em cada grupo correspondiam à essência social do grupo. Quando se observou inclusão errônea de elementos, estes foram transferidos para outros grupos, a cujas qualidades essenciais eles correspondiam. Depois disso, construiu-se o retrato do status do grupo dentro de classificações precisas; o procedimento repetiu-se até o grupo tornar-se suficientemente homogêneo, segundo os seus principais traços de status.

Os diferentes grupos foram identificados com o auxílio de diferentes conjuntos de características; por isso, com a definição independente dos limites de suas classificações, eles sobrepor-se-iam em algumas partes. Para evitar isso, estabeleceu-se uma hierarquia dos status. A primeira prioridade foi dada à participação dos entrevistados na atividade empresarial; a segunda, ao desempenho de funções de gerência e de trabalho profissional na área de negócios. O estudo da comunidade portadora dessas características ("a camada de negócios") constituiu uma etapa especial do trabalho (8). Os entrevistados, que não tinham relação com a área de negócios e desempenhavam trabalho assalariado, foram divididos em trabalhadores ocupados em trabalho predominantemente intelectual ou predominantemente físico, dependendo do status do seu cargo profissional. Este se definiu pela combinação das respostas às perguntas: "Precisamente que trabalho você desempenha? (Descreva-o em pormenor)" e: "Em qual dos seguintes grupos de cargos profissionais você se incluiria?" Nos casos de divergência de informações, em regra, deu-se preferência às respostas à primeira pergunta. No passo seguinte, os trabalhadores ocupados em atividades predominantemente intelectual foram divididos em três grupos de qualificação, e os trabalhadores ocupados em atividade predominantemente física, em grupos por setores da economia e níveis de qualificação.

Resultados gerais da identificação dos grupos e camadas - O monitoramento das mudanças econômicas e sociais na Rússia, em seu quarto ano de realização pelo CRPOP, permite identificar e estudar grande parte dos grupos e camadas do nosso interesse; mas alguns escapam a ele. Em particular, consegue-se representar a camada superior da sociedade apenas pelo grupo de sub-elite de grandes e médios empresários; a elite governante propriamente dita - os dirigentes políticos do centro e das regiões, os funcionários de alto escalão, o generalato e outros - por uma ou outra razão não estão incluídos nas amostras (9). As camadas média e básica, com todos os grupos que as compõem, são as representadas de forma mais confiável e completa em nossa pesquisa. A camada inferior foi por ora identificada em forma bruta: limita-se aos trabalhadores não-qualificados da cidade. No futuro, cabe elaborá-la melhor.

No que concerne à "subclasse social" semicriminosa, seus representantes ou não aparecem na amostra por falta de domicílio permanente ou de seu registro, ou são evitados pelos entrevistadores, ou, participando da amostra e participando da pesquisa, não se identificam como tais. Esta camada, assim como a elite, estuda-se com métodos especiais.Finalmente, dividimos o universo estudado em 14 grupos, referentes às quatro camadas sociais, conforme segue. 


\begin{tabular}{|c|c|}
\hline Grupos sociais & madas sociais \\
\hline 1 Médios e grandes empresários & Superior \\
\hline 2 Pequenos empresários & Média \\
\hline 3 Semi-empresários & $"$ \\
\hline 4 Gerentes da esfera produtiva & $"$ \\
\hline 5 Gerentes da esfera não-produtiva & " \\
\hline 6 Especialistas prósperos & " \\
\hline 7 Elite trabalhadora & $"$ \\
\hline 8 Oficiais militares superiores & $"$ \\
\hline 9 A massa da inteligentsia (especialistas) & Básica \\
\hline 10 Semi-inteligentsia (auxiliares de especialistas, servidores técnicos) & " \\
\hline 11 Trabalhadores do comércio e dos serviços & $"$ \\
\hline 12 Trabalhadores de média qualificação & $"$ \\
\hline 13 Camponeses & $"$ \\
\hline 14 Trabalhadores não-qualificados & Inferior \\
\hline
\end{tabular}

As características do status social dos grupos enumerados são apresentadas em pormenores no trabalho A estrutura da sociedade russa contemporânea (10). Aqui, nos deteremos apenas nas particularidades das camadas sociais por eles formadas.

\section{Particularidades sociais \\ das camadas da sociedade russa}

Relação quantitativa das camadas - Apesar do nosso desejo de utilizar todo o conjunto de informações constantes da amostra do Monitoramento, foi necessário excluir da análise parte dos questionários (de 10\% em 1993 a 24\% em 1995), porque neles não constavam importantes características de status. A verificação dos entrevistados excluídos mostrou que a sua estrutura, de acordo com a maioria dos indicadores de status, não se distingue da do conjunto restante. Conseqüentemente, não é grande a influência dessa exclusão na classificação quantitativa dos vários grupos e camadas. É mais complexa a questão da amostra do Monitoramento, que inevitavelmente se desvia, em maior ou menor grau, da amostra planejada; isso sem considerar o conjunto da população. Para a reconstituição das características planejadas da amostra, o CRPOP elabora um questionário "ponderado". No entanto, ele inclui um círculo reduzido de variáveis e, em uma série de casos, diminui a representatividade da amostragem para outros parâmetros. Desse modo, os dados do Monitoramento sobre o número relativo dos grupos e das camadas representam apenas uma primeira aproximação à real estrutura da sociedade russa. 
No triênio 1993-1995, a relação entre as camadas da sociedade russa por nós distinguidas era 1: 24: 68: 7. Isso significa que as camadas superior e média, que constituem os principais propulsores das reformas, representavam um quarto da população economicamente ativa. Nos países desenvolvidos do Ocidente, a classe média, formada por grupos sócio-profissionais análogos, compõe a parcela básica da população e ocupa uma posição muito mais alta. A conjugação desses traços confere-lhe o papel de estabilizadora da sociedade. Na Rússia, os grupos correspondentes são menos desenvolvidos, apresentam outras características sócio-culturais e têm um status muito mais baixo. A camada média, como já foi observado, encontra-se aqui em "estado embrionário". Não obstante isso, o seu papel na vida da sociedade e no processo de transformação é muito grande e crescerá no futuro.

A maioria dos russos pertence à camada básica da sociedade, comparativamente pouco diferenciada. No fundamental, o conteúdo de seu trabalho corresponde ao estágio industrial de desenvolvimento da sociedade. A importância social dessa camada está relacionada com o fato de que ela concentra a maior parte do potencial de trabalho e de consumo da Rússia, do seu eleitorado e das Forças Armadas. Comparativamente às camadas superior e média, os seus interesses são menos articulados e o seu comportamento nas esferas dos negócios e da política, caracteriza-se por uma atuação menor. No entanto, em situações críticas, o ânimo social e o comportamento dessa camada podem tornar-se o fator determinante do desenvolvimento histórico da Rússia. A camada inferior, por nossos cálculos, perfaz menos de um décimo da população economicamente ativa, mas, considerando-se os grupos lumpenizados da população não-incluídos nas pesquisas, a sua participação não será menor que de 12 a 15\%.

Potencial sócio-demográfico - As camadas da sociedade russa possuem diferentes potenciais de ação e adaptação, isto é, diferentes capacidades de incluir-se na formação de novas instituições sociais, de participar no seu desenvolvimento e fortalecimento, de usá-las em seu interesse, de adaptar-se ativamente à realidade mutante e, em conseqüência disso, de melhorar o seu status ou pelo menos mantê-lo. Daí o papel qualitativamente diferente dessas camadas no processo de transformação. A capacidade para a atividade socialmente inovadora e para o comportamento adaptador eficaz depende do potencial sócio-demográfico das camadas, do qual algumas características são mostradas na tabela 1.

Os dados revelam um quadro de desigualdade substancial, determinado pelas características das pessoas que o compõem. É especialmente grande a diferença de posição dos homens e das mulheres: na camada superior, o número de mulheres é quatro vezes menor do que na camada inferior; o dos homens é três vezes maior, o que dispensa comentários. Também se confirma inteiramente o fato de que as gerações mais jovens se adaptam às novas condições com muito mais facilidade e eficácia do que as mais velhas. Na camada superior, em relação à inferior, há duas vezes mais jovens e 20 vezes menos pessoas idosas. $\mathrm{O}$ aspecto nacional da estratificação da sociedade russa expressa-se no fato de que, nas ca- 
madas superiores, a participação relativa da população não-russa é maior nas camadas superiores do que nas inferiores. Os representantes das camadas sociais comparadas distinguem-se substancialmente quanto ao local de domicílio. Como se sabe, as cidades grandes, com o seus ricos meios de informação, propiciam aos habitantes maiores possibilidades de socialização, realização pessoal e adaptação às condições mutantes, em relação às povoações menores. Os dados da tabela mostram que a camada superior pende mais para as cidades grandes e capitais, ao passo que os representantes das camadas básica e inferior moram mais freqüentemente em cidades pequenas e em povoados.

Tabela 1

Rússia. Características sócio-demográficas das camadas sociais (\% com relação ao total de pessoas de cada camada)

\begin{tabular}{|c|c|c|c|c|}
\hline \multirow[b]{2}{*}{ Indicadores } & \multicolumn{4}{|c|}{ Camadas sociais } \\
\hline & superior & média & básica & inferior \\
\hline \multicolumn{5}{|l|}{ Idade } \\
\hline Menos de 30 anos & 39 & 24 & 24 & 21 \\
\hline $30-59$ anos & 60 & 61 & 58 & 58 \\
\hline 60 anos e mais & 1 & 15 & 18 & 21 \\
\hline \multicolumn{5}{|l|}{ Sexo } \\
\hline Homens & 83 & 61 & 41 & 31 \\
\hline Mulheres & 17 & 39 & 59 & 69 \\
\hline \multicolumn{5}{|l|}{ Nacionalidade } \\
\hline Russos & 80 & 86 & 86 & 88 \\
\hline Outras nacionalidades & 20 & 14 & 14 & 12 \\
\hline \multicolumn{5}{|l|}{ Local de domicílio } \\
\hline Moscou, São Petersburgo & 30 & 24 & 19 & 19 \\
\hline Outras cidades grandes & 32 & 27 & 24 & 25 \\
\hline Cidades médias e pequenas & 29 & 31 & 32 & 37 \\
\hline Aldeia ou povoado do tipo urbano & 9 & 18 & 24 & 19 \\
\hline Índice de urbanização (11) & 0,54 & 0,47 & 0,42 & 0,43 \\
\hline \multicolumn{5}{|l|}{ Instrução } \\
\hline Superior, inclusive incompleta & 62 & 49 & 25 & 6 \\
\hline Média especializada & 22 & 26 & 32 & 19 \\
\hline Média geral, inclusive incompleta & 16 & 25 & 43 & 75 \\
\hline \multicolumn{5}{|l|}{ Auto-avaliação da qualificação } \\
\hline Alta & 45 & 43 & 32 & 12 \\
\hline Média & 41 & 48 & 56 & 48 \\
\hline Baixa & 14 & 9 & 12 & 40 \\
\hline
\end{tabular}


Qualidades como instrução, profissionalismo e qualificação são características de maior peso na camada superior da sociedade, sendo de três quintos do total de seus componentes os que possuem formação universitária. A proporção de pessoas, que avaliam como alta a sua qualificação, também é maior nesta camada em relação às demais. Ao mesmo tempo, chama atenção a proporção de pessoas que consideram baixa a sua qualificação ou encontram dificuldade em avaliá-la. Pelo visto, isso está relacionado com o não-desenvolvimento das orientações de formação do indivíduo para a atividade empresarial. A camada média fica pouco atrás da superior em relação à quantidade de pessoas com instrução especializada, porquanto em sua composição, além de especialistas, há semi-empresários e operários qualificados. Nela, no entanto, a relação entre as avaliações alta e baixa da qualificação é a mais favorável. Tal fato pode ser reflexo não apenas do nível como também da qualidade da instrução recebida em prestigiados estabelecimentos de ensino superior das capitais, da formação em pós-graduação e dos graus e títulos científicos obtidos. Tudo isso é muito próprio da camada média. Na camada básica, as pessoas com formação especializada compõem aproximadamente a sua metade, mas a instrução da maior parte delas é de nível médio. Os especialistas com instrução superior, nela, são em número duas vezes menor do que na camada média, e duas vezes e meia menor do que na superior.

Na auto-avaliação de sua qualificação, predomina a média. A camada inferior distingue-se das outras tanto pela proporção de pessoas com formação especializada, quanto pela avaliação da sua qualificação como baixa, mesmo em se tratando das profissões mais simples. Dois quintos dos seus representantes ou encontram dificuldade em definir o nível de sua qualificação ou a estimam como baixa. Somente $2 \%$ continuam a estudar (contra $8 \%$ na camada superior e $5 \%$ nas camadas média e básica).

O que foi dito acima evidencia que as camadas da sociedade russa dispõem de premissas sócio-demográficas muitíssimo diferentes para adaptação às novas condições e participação na atividade socialmente inovadora. Vejamos como elas conseguem-se haver com tais premissas.

Status sócio-econômico - Para a avaliação do status das camadas estudadas utilizamos os seguintes indicadores: domínio de propriedade produtiva (capital), status da ocupação, setor de ocupação segundo a forma de propriedade, esfera social do ramo de ocupação, lugar na hierarquia administrativa ( status do cargo), grau de bem-estar. Os valores desses indicadores são mostrados na tabela 2 .

A camada superior é formada por proprietários de empresas e firmas privadas. Os seus representantes ocupam lugar importante na hierarquia de gestão da economia, porquanto tomam decisões estratégicas e determinam as linhas principais do desenvolvimento dos negócios. Pelos seus indicadores de nível de vida, essa camada se distingue substancialmente das demais. O crescimento de sua renda, em níveis sempre superiores ao dos preços, leva à concentração de uma proporção cada vez maior da riqueza social nas suas mãos. A composição da 
camada média é mais variada: aproximadamente um terço dos seus representantes dirigem suas próprias firmas ou se ocupam em negócio individual, e muitos conciliam a condução de negócio próprio com um trabalho profissional assalariado. Predomina a ocupação nos setores privado e acionário da economia. O potencial gerencial dessa camada é menor do que o da superior, mas, ainda assim, é respeitável: um quarto dela é constituído de diretores e gerentes de empresas, organizações e autarquias, sendo a proporção dos que se autoclassificam como dirigentes ainda mais alta. Parcela considerável dessa camada é composta de especialistas, que desempenham funções de comando. O nível de bem-estar da camada média é 2,5-3 vezes mais baixo do que o da superior e, na mesma proporção, mais alto do que o da camada básica. A maioria dos seus representantes vive em nível de suficiência, ainda que relativa. No que concerne às camadas básica e inferior, os seus status sócio-econômicos não diferem muito entre si. Ambas as camadas são representadas por trabalhadores tarefeiros, empregados fundamentalmente no setor estatal. A diferença consiste em que a situação econômica da camada básica pode ser definida como difícil, enquanto a da inferior é crítica.

Tabela 2

Rússia. Características do status social

(\% em relação ao total de pessoas de cada camada)

\begin{tabular}{|c|c|c|c|c|}
\hline \multirow[t]{2}{*}{ Indicadores } & \multicolumn{4}{|c|}{ Camadas sociais } \\
\hline & superior & média & básica & inferior \\
\hline \multicolumn{5}{|l|}{ Posse de capital e tipo de ocupação } \\
\hline Proprietários de empresas e firmas & 100 & 18 & 0 & 0 \\
\hline Proprietários de outros tipos de capital & 0 & 14 & 0 & 0 \\
\hline Trabalhadores assalariados & 0 & 71 & 100 & 100 \\
\hline \multicolumn{5}{|l|}{ Setor da economia (forma de propriedade) } \\
\hline Estatal & 0 & 41 & 67 & 72 \\
\hline Acionária & 0 & 31 & 28 & 25 \\
\hline Privada & 100 & 29 & 5 & 3 \\
\hline \multicolumn{5}{|l|}{ Tipo de trabalho executado } \\
\hline Dirigentes & 100 & 37 & 0 & 0 \\
\hline Especialistas & 0 & 23 & 20 & 0 \\
\hline Outros & 0 & 40 & 80 & 100 \\
\hline \multicolumn{5}{|l|}{ Status do cargo (auto-avaliação) } \\
\hline Dirigentes & 84 & 33 & 4 & 0 \\
\hline Especialistas & 9 & 29 & 38 & 1 \\
\hline Outros & 7 & 37 & 58 & 99 \\
\hline \multicolumn{5}{|l|}{ Nível de bem-estar } \\
\hline Bem-estar, abastança & 70 & 30 & 5 & 3 \\
\hline Suficiência relativa, necessidade & 30 & 56 & 49 & 32 \\
\hline Pobreza, miséria & 0 & 14 & 46 & 65 \\
\hline Sem diminuição do poder aquisitivo & 66 & 27 & 11 & 8 \\
\hline
\end{tabular}


Diferenciação das rendas reais - O principal e mais perverso elemento da estratificação da sociedade russa é a desigualdade material dos grupos e camadas sociais. Os indicadores de diferenciação da renda refletem a influência de um amplo leque de fatores econômicos, sociais e demográficos. Por causa disso, a desigualdade material, importante em si mesma, torna-se expressão de muitas outras desigualdades sociais: de gênero, de idade, urbanísticas, rurais, de ramo, profissionais, de administração etc. O nível da renda, por sua vez, influi substancialmente nos aspectos relativos ao status social, como tipo de consumo e modo de vida, possibilidade de ocupar-se de negócios, estabelecer ligações sociais proveitosas, subir na carreira profissional, dar aos filhos uma instrução de qualidade e assim por diante. Por isso, a diferenciação da renda constitui a base da estratificação social, pelo menos no caso da Rússia contemporânea.

Nípel e dinâmica da renda - A maioria dos russos esperava que a perestroika trouxesse um crescimento rápido, ainda que não imediato, do bem-estar e a melhoria das condições de vida. Na realidade, no entanto, as reformas de mercado acarretaram uma drástica piora da sua situação material. Em 1992, o nível médio dos preços ao consumidor elevou-se 26 vezes e o das rendas monetárias, somente 11 vezes. Em conseqüência, as rendas reais da população tornaram-se 2,3 vezes menores e as poupanças desvalorizaram-se completamente. Em 1993, a situação estabilizou-se: os preços ao consumidor aumentaram aproximadamente 10 vezes e as rendas da população, 11 vezes (12). Os dados sobre a dinâmica das rendas reais da população nos anos seguintes são contraditórios. Segundo algumas fontes (Monitoramento do CRPOP), elas cresceram um pouco; de acordo com outras (Direção Central de Estatística da Federação Russa), elas, ao contrário, diminuíram. Entretanto, qualquer que seja essa dinâmica, atualmente as rendas reais dos russos não ultrapassam 40-50\% do seu nível da metade dos anos 80 . Alguma elevação do seu nível médio, se ocorre, deve-se à renda da parte mais abastada da população, pois as rendas da sua grande massa se reduziram. Não sem razão a parcela dos russos que consideram "ruim" a sua situação financeira, aumentou de $42 \%$ em 1993 para 49\% em 1995; e a parcela dos que a avaliaram como "muito ruim" foi de 8 para $12 \%$ no mesmo período (13). Também mudou a estrutura da renda da população. No final dos anos $80,72 \%$ delas eram formadas pelos salários, $14 \%$ pelas transferências sociais, e outros $14 \%$ pelos rendimentos provenientes da propriedade e da atividade empresarial (14); em 1995, a relação entre essas fontes na composição da renda foi de respectivamente $40 \%$, $16 \%$ e $44 \%$ (15). Sabendo-se que é de $10 \%$ a participação da população em atividade empresarial, isso por si só fala da polarização da pobreza e da riqueza.

Realmente, na primeira metade dos anos 80 , o coeficiente de diferenciação da renda da população da URSS por quartís foi de pouco mais de duas vezes, por decís de 3,5 vezes, o que permitia aos ideólogos falar da conquista de homogeneidade social. O segredo consistia em que parcela fundamental do consumo das camadas superiores não se mediatizava através do dinheiro, mas se realizava por meio do acesso gratuito a bens e a subsídios e privilégios ocultos. A existência desse sistema era mascarada com a concessão, a todos os cidadãos, de 
certa quantidade de serviços médicos e de educação gratuitos, habitação barata, vagas em instituições infantis, direito a descanso em colônia de férias e outras. Desse modo, as diferenças acentuadas no bem-estar das camadas inferiores e superiores conjugavam-se com a visibilidade de uma distribuição "justa" da renda. O desenvolvimento das relações de mercado destruiu esse frágil equilíbrio. A esfera da distribuição gratuita e subsidiada de bens escassos aos poderosos do mundo diminuiu substancialmente. O mercado consumidor recebeu grande quantidade de mercadorias importadas, que são adquiridas somente a dinheiro. Simultaneamente, começou a ruir o sistema paternalista de serviços sociais (médicos, educacionais, habitacionais entre outros) prestados à população: para seu pagamento exige-se cada vez mais dinheiro. Dessa maneira, a proporção da renda na forma natural diminuiu, aumentando sensivelmente a necessidade de dinheiro para a manutenção do nível de vida alcançado.

As várias categorias da população puderam satisfazer a essa necessidade de modo desigual. Em conseqüência, a polarização do bem-estar começou a crescer sensivelmente. De acordo com os dados de pesquisas especiais, no fim dos anos 80 , o coeficiente de diferenciação das rendas por decís da população não ultrapassava 4,5 vezes; em 1993, alcançou 7,8 vezes (16), e no outono de 1995, já alcançou 10,5 vezes (17). As estatísticas oficiais fornecem um quadro semelhante: 1991 - 5,5 vezes; 1993 - 11 vezes; e 1995 - 13 vezes (18). Em 1994, 10\% dos cidadãos mais abastados detinham $40 \%$ da renda total da população, cabendo à absoluta maioria da população os $60 \%$ restantes (18). No outono de 1995 , a diferença entre os níveis da renda percebida por $10 \%$ dos russos mais e menos abastados chegava a quase 25 vezes. Criados com base em valores igualitários, os russos consideram a polarização da pobreza e da riqueza como crescimento da injustiça social.

As rendas das camadas sociais - Com que intensidade se diferenciam os níveis de renda das camadas sociais examinadas por nós? Quais são as suas reivindicações de renda e como são atendidas as suas pretensões? Para responder a essas perguntas, utilizamos os seguintes indicadores do Monitoramento:

- nível das rendas monetárias básicas e complementares dos trabalhadores (RMT);

- nível da renda familiar per capita (RFK);

- concepções subjetivas sobre o nível do salário mínimo necessário (SMN);

- opiniões sobre o valor do mínimo de sobrevivência por membro da família (SMF);

- concepção sobre o nível de renda per capita suficiente para "assegurar uma vida normal" (RKSV);

- relação entre as concepções sobre o valor do mínimo de sobrevivência por membro da família e o nível de renda per capita suficiente para "assegurar uma vida normal" (MSF/RKSV); 
- relação entre a renda factual e as concepções sujetivas sobre o salário mínimo necessário (RMT/SMN);

- relação entre a renda factual familiar per capita e o nível de renda concebido como suficiente para assegurar uma vida normal (RFK/RKSV).

O nível da renda monetária dos trabalhadores estabelecido no Monitoramento caracteriza-se por sua conhecida inconsistência. Em primeiro lugar, a pergunta correspondente no questionário refere-se somente às rendas pessoais, deixando de lado o lucro empresarial. Em segundo, estabelece os valores liquidos, i.e., a renda dos trabalhadores após o pagamento dos impostos. Em terceiro, a maioria dos entrevistados, ao responderem a essa pergunta, reduzem a sua renda, a fim de não atrair a atenção do fisco ou dos órgãos de segurança; isso para não falar dos ladrões e dos extorsionários: quanto mais altas as rendas, mais elas são diminuídas. Em quarto, o Monitoramento não leva em conta as rendas na forma natural que influem bastante no bem-estar material de alguns grupos de russos (em particular, habitantes da zonas rurais, militares, trabalhadores com cargos de direção e outros).

Em vista disso, os dados apresentados em seguida fornecem apenas um quadro aproximado da real distribuição de renda.

Se se considerar como $100 \%$ o nível médio de renda dos russos economicamente ativos, a renda média da camada superior comporá $516 \%$, da média $144 \%$, da básica $-75 \%$ e da inferior $-54 \%$. A diferença entre as camadas superior e inferior é de quase dez vezes, e, entre a média e a inferior, de aproximadamente três. Mas, se se considerar a parte da renda das camadas superiores não levada em conta e suas poupanças e imóveis, a diferenciação material das camadas estudadas se revelará significativamente maior. O nível da renda familiar per capita é um pouco menos diferenciado: a diferença entre as camadas sociais situadas nos extremos é de aproximadamente sete vezes. A comparação com os dados apresentados sobre a dispersão geral das rendas da população mostra que a estratificação da sociedade explica uma parte substancial dele.

Pretensões subjetivas de renda - E como a própria população avalia o nível de sua renda e o grau de sua diferenciação? Para respondermos a essa pergunta, analisemos as concepções dos russos sobre dois indicadores de renda, capazes de servir como determinados critérios de avaliação - o salário mínimo necessário (SMN) e a renda per capita suficiente (RKSV). Os valores absolutos dos indicadores citados refletem as pretensões subjetivas das pessoas com relação ao nível de bem-estar pessoal, à qualidade e ao modo de vida, à sofistificação das suas necessidades sociais e aos tipos de objetivos almejados. Já a diferença entre as idéias sobre a renda suficiente (RKSV) e o mínimo de sobrevivência (MSF) espelha a distância social que o indivíduo, o grupo ou a camada social interpõem em pensamento entre si e as camadas menos favorecidas da sociedade. No triênio 1993-1995, em média, essa diferença era de menos de duas vezes e meia para todos os russos, o que, a nosso ver, revela as sérias auto-restrições impostas pelas pessoas às suas próprias aspirações em relação aos níveis de vida e de renda. 
Dinamicamente, a diferença entre esses indicadores apresenta crescimento: em 1993, ela era de 2,3 vezes; em 1994, de 2,4 vezes e, em 1995, de 2,6 vezes. Isso pode indicar tanto alguma redução da estimativa do mínimo sobrevivência e a formação de uma concepção mais modesta do seu conteúdo material, quanto o aumento das aspirações das massas em relação ao próprio nível de bem-estar. Em favor da primeira suposição há o fato de que, de ano para ano, as concepções dos russos sobre o mínimo de sobrevivência tem se consolidado e a sua dispersão diminui. Atualmente, a diferença entre as concepções das camadas sociais situadas nos extremos sobre o mínimo de sobrevivência per capita perfaz apenas $40 \%$; essa diferença entre as camadas média e inferior é de menos de $20 \%$. Tais diferenças parecem-nos naturais e justificadas. Já sobre as rendas suficientes a questão é outra.

Realmente, o nível de renda per capita suficiente para assegurar "uma vida normal", apontado pelos entrevistados, representa uma apreciação indireta do bem-estar que satisfaz às necessidades básicas. Na base desse indicador, repousam concepções subjetivas, muito variadas, dos indivíduos e dos grupos sobre o que significa "ter uma vida normal". Para os representantes das gerações mais velhas, das camadas básica e inferior da sociedade e da maioria da população dos povoados e pequenas cidades, as concepções sobre renda suficiente estão relacionadas com a satisfação de necessidades tradicionais relativamente limitadas. Para a maioria deles, viver "normalmente" significa viver "como antes". Já a maior parte dos jovens, dos habitantes das capitais, empresários, especialistas de alta classe e dos empregados na área de negócios, ao contrário, está orientada para valores modernos. Por isso, mais provavelmente, consideram "normal" uma vida como a que se tem no Ocidente.

No presente, as pretensões subjetivas dos russos em relação ao nível de bem-estar pessoal, à qualidade e ao modo de vida sofrem duas influências opostas. A persistente queda do nível de vida obriga parte significativa da população a limitar o seu consumo e a abster-se de muitos elementos do seu modo anterior de vida: compra de alimentos caros, de roupa e calçado da moda, da utilização dos serviços oferecidos à população, de viagens turísticas, de tratamento em sanatórios, da assinatura de revistas, de telefonemas interurbanos etc. Em conseqüência de se terem gradualmente acostumado à piora das condições de vida, as concepções das pessoas sobre o nível de renda suficiente tornam-se mais reduzidas. Ao mesmo tempo, a propaganda obsessiva do modo de vida dos "novos russos" e dos modelos ocidentais de consumo, feita pelos meios de comunicação, provoca o aumento das pretensões em relação à renda, principalmente entre os jovens e os grupos econômicos prósperos.

É natural esperar que as concepções dos vários grupos e camadas sociais sobre o nível de renda suficiente sejam muito mais diferenciadas do que as concepções sobre o mínimo de sobrevivência; pois quem quer que determine o seu nível, sempre terá em mente o estrato menos favorecido, necessitado da ajuda da sociedade para arrumar-se. Nesse sentido, as categorias de mínimo de sobrevivência ou renda mínima do trabalhador têm um sentido mais ou menos "absoluto". Já o conceito de renda suficiente refere-se ao próprio entrevistado e à sua 
família; ele não pode deixar de depender nem do nível de vida factual das pessoas nem das suas características subjetivas, em particular do nível das suas ambições. Por isso, era de se crer que a diferença das reivindicações das camadas superior e inferior da sociedade com relação ao nível de renda "suficiente" fosse muito elevada. Os dados do Monitoramento, porém, não indicam isso. É bem verdade que, à medida que se eleva o status das camadas sociais, as suas concepções sobre o nível suficiente de renda também se elevam. No entanto, a diferença que nos interessa, a existente entre as camadas superior e inferior, é de apenas duas vezes. $\mathrm{E}$ isso para uma diferença de quase dez vezes no nível das rendas efetivamente recebidas! Já as "tesouras" entre as concepções das diferentes camadas sociais sobre os níveis mínimo e "suficiente" de renda divergem ainda menos. A distância social que a camada superior interpõe entre ela e a linha de pobreza é de 3,3 vezes; na camada média, ela é de 2,6 vezes; nas camadas básica e inferior, 2,3 vezes. A nosso ver, tal fato é muito significativo e merece uma análise complementar. Por um lado, ele atesta a incrível vitalidade das concepções e valores niveladores, indomáveis até pela economia de mercado: a maioria dos russos não aceita uma forte diferenciação de renda e não se convence da sua necessidade para o desenvolvimento eficiente da economia. Por outro lado, o mesmo fato pode refletir fenômenos de uma ordem completamente diferente: a queda catastrófica do nível de vida da maioria dos russos, combinada com a destruição da antiga estratificação social e a formação de outra, inteiramente nova, baseada na riqueza. Ao caírem nos estratos inferiores, as pessoas antes abastadas mantêm altas pretensões, enquanto os pobres enriquecidos apresentam reivindicações relativamente moderadas em relação à renda.

Grau de satisfação das pretensões em relação à renda-Para determinar qual dessas suposições está mais próxima da verdade, tentemos avaliar o grau de satisfação das pretensões econômicas das camadas examinadas. Para tal usamos dois indicadores:

- a relação entre a renda efetiva das famílias e a concepção sobre o seu nível suficiente;

- a relação entre a renda monetária efetiva dos trabalhadores e o nível do salário mínimo necessário, na opinião deles.

Examinemos, primeiro, as cifras médias e, depois, as particularidades das camadas sociais. Antes de mais nada, queremos assinalar que pretensões mais altas em relação à renda, em comparação ao seu nível efetivo, constitui um fenômeno natural, geral e positivo, que em regra motiva as pessoas ao exercício profissional mais ativo, ao aumento da qualificação, à participação na área de negócios e assim por diante. A questão está apenas na medida. Se a diferença entre o salário efetivo e a renda que, na opinião da pessoa, assegura "uma vida normal" ultrapassa determinado limite, o estímulo à ativização de uma atividade construtiva é substituída pela apatia, pelo alheamento ao trabalho, pelo crescimento do protesto e por métodos menos convencionais e até criminosos de satisfação das suas aspirações. Em média, o nível da renda per capita da população russa, entre 
1993 e 1995, constituía apenas um terço do nível que era considerado suficiente. Sob esse aspecto, a situação da camada superior era muito distinta da das outras: a sua renda ficava apenas $20-25 \%$ aquém do nível desejado, o que incentivava os seus representantes ao aumento da atividade de negócios, à ampliação do campo de atuação e assim por diante. A renda da camada média era 2,5 vezes menor do que o nível subjetivamente suficiente; a das camadas básica e inferior 3,3 e 4 vezes, respectivamente. Tal distância entre o estímulo e a realidade, a nosso ver, é destrutiva. Ela conduz ou à resignação, à miséria, e à degradação social, ou à luta pela sobrevivência a qualquer preço, inclusive ao comportamento amoral e criminoso. Surge a questão, o que refletem os dados: o nível de vida extraordinariamente baixo dos russos ou o nível injustificadamente alto das suas aspirações.

$\mathrm{Na}$ bibliografia científica encontra-se ambos os tratamentos da questão. Alguns estudiosos enfatizam o dramático empobrecimento do povo (19); outros, põem em relevo a desproporcionalidade entre as aspirações subjetivas dos russos, de um lado, e a eficiência do seu trabalho e a situação da economia, do outro (20). Nós tendemos a solidarizar-nos com a primeira atitude, com base nos seguintes argumentos: em primeiro lugar, é muito fácil mostrar que a norma de bem-estar, para a qual a maioria dos russos se orienta, reflete, ao contrário do que se afirma às vezes, não o modo de vida da classe média estadunidense, propagandeada pela televisão, mas os bem conhecidos modo e nível de vida, que os próprios russos conheceram durante muitos anos, até às vésperas das reformas; em segundo, a renda média do trabalhador russo, em 1995, perfazia apenas quatro quintos (em 1993, tão-somente dois terços) da concepção massiva da população sobre o salário mínimo necessário.

Além disso, a diferença no grau de satisfação das aspirações das diferentes camadas sociais, entre 1993 e 1995, era de seis vezes: o nível efetivo de renda dos trabalhadores pertencentes às camadas superior e média perfazia $280 \%$ e $120 \%$, respectivamente, das concepções dessas camadas sobre o salário mínimo necessário. Não são indicadores muito altos, mas, em uma situação crítica, toleráveis. As rendas das camadas básica e inferior da sociedade perfaziam, respectivamente, 55-60\% e 40-45\% das suas concepções de renda mínima necessária, o que é insuportável. Os indicadores apontados, por um lado, confirmam o empobrecimento crítico da maioria dos russos e, por outro, atestam que o nível contemporâneo das rendas não consegue estimular a atividade laboral e comercial da grande massa da população economicamente ativa.

Adaptabilidade às novas condições sociais - $\mathrm{Na}$ qualidade de característica indireta da adaptabilidade das várias classes sociais à realidade mutante pode ser examinado o seu estado de ânimo social. Quanto melhor ele for, tanto mais prováveis serão a participação ativa das correspondentes camadas na atividade social inovadora e uma bem sucedida adaptação; quanto pior, tanto mais provável a sua incapacidade para adaptar-se às novas condições. Para a avaliação da adaptabilidade social das pessoas, usamos três perguntas do questionário:

- Como avalia o bem-estar da sua família? (respostas: muito bom, bom, médio, ruim, muito ruim, não soube responder); 
- Qual das afirmações seguintes lhe parece mais correta? (respostas: "as coisas não estão tão mal, e pode-se viver", "a vida está difícil, mas se pode agüentar", "a nossa situação miserável é insuportável”, não soube responder);

- Que poderia dizer sobre o seu estado de ânimo nos últimos dias? (excelente; normal; sem oscilações; irritado, tenso; sinto angústia e medo; não soube responder) (Tabela 3 ).

Tabela 3

Rússia: estado de ânimo das camadas sociais (\%)

\begin{tabular}{|c|c|c|c|c|}
\hline \multirow[b]{2}{*}{ Indicadores } & \multicolumn{4}{|c|}{ Camadas sociais } \\
\hline & superior & média & básica & inferior \\
\hline \multicolumn{5}{|l|}{ Auto-avaliação do bem-estar } \\
\hline Bom, muito bom & 37 & 13 & 5 & 3 \\
\hline Médio & 52 & 60 & 52 & 46 \\
\hline Ruim, muito ruim & 11 & 27 & 43 & 51 \\
\hline \multicolumn{5}{|l|}{ Auto-avaliação das condições de vida } \\
\hline As coisas não estão tão mal, pode-se viver & 46 & 17 & 8 & 5 \\
\hline A vida está difícil, mas se pode agüentar & 42 & 52 & 54 & 52 \\
\hline A situação miserável é insuportável & 10 & 25 & 32 & 36 \\
\hline \multicolumn{5}{|l|}{ Estado de âmimo geral } \\
\hline Excelente; normal; sem oscilações & 67 & 52 & 44 & 38 \\
\hline Tenso, irritado & 25 & 38 & 44 & 43 \\
\hline De angústia, medo & 4 & 5 & 7 & 12 \\
\hline
\end{tabular}

A pergunta sobre o bem-estar toca o mais delicado dos problema para os entrevistados. No conjunto, as respostas a ela são pessimistas, mas, para as várias camadas, a sua estrutura é muito diferenciada. Os representantes da camada superior avaliam a sua situação material como positiva com freqüência três vezes maior que como negativa. Na camada média, a relação parece mais ser inversa, enquanto, nas camadas básica e inferior, as auto-avaliações positivas são 10-15 vezes mais raras do que as negativas. A segunda pergunta é de caráter mais abrangente; além disso, o seu sentido está bem mais próximo da revelação das possibilidades de adaptação dos entrevistados. A resposta "As coisas não estão tão mal, pode-se viver" é escolhida pelas pessoas que se adaptaram à nova realidade, relativamente prósperas e esperançosas de um futuro melhor. A resposta "A vida está difícil, mas pode-se agüentar" caracteriza a situação intermediária, própria da maior parte da sociedade, enquanto a afirmação "A situação miserá- 
vel é insuportável" evidencia cansaço profundo, decepção e perda das esperanças. A relação entre a proporção dos entrevistados, que escolheram a primeira e a dos que escolheram a terceira avaliações, pode ser considerada uma medida do otimismo social. Na camada superior, essa medida é 460\%; na média, $70 \%$; na básica, $25 \%$, e, na inferior, $14 \%$. A última pergunta tem caráter de controle. Ela refere-se a um momento concreto da vida, e as respostas a ela dependem de muitas circunstâncias, que vão desde a situação de saúde e das relações familiares até a êxitos e malogros casuais. No entanto, quando se comparam as grandes camadas, a influência de fatores casuais se compensam, o que permite revelar algumas tendências estáveis. Se relacionarmos o número de entrevistados, que caracterizam o seu estado de ânimo de "excelente, normal e sem oscilações", ao número dos que sentem "tensão, irritação ou angústia e medo", o indicador do estado de ânimo da camada superior será $230 \%$, da média $120 \%$, da básica $90 \%$ e da inferior $70 \%$.

A partir dos dados apresentados pode-se avaliar o estado de ânimo social da camada superior como otimista e seguro, da camada média como tranqüilo e estável, das camadas básica e inferior como médio e máximo de cansaço e desesperança, respectivamente. Isso mostra que a estrutura da sociedade russa contemporânea apresenta um caráter de desequilíbrio, porquanto a sua parcela fundamental, constituída pela camada básica, encontra-se em situação extremamente desfavorável. O baixo status e a difícil situação material não permitem a essa camada encontrar um lugar digno na economia de mercado e se adaptar às novas condições econômicas, o que provoca o aumento da sua insatisfação. Por ora, esta tem se expressado de forma predominantemente verbal; mas, nos dois últimos anos, o movimento operário tem crescido, e se torna uma oposição cada vez mais clara à política do governo. Se a situação das camadas básica e inferior continuar a piorar, ela pode ameaçar a estabilidade social.

\section{Dinâmica das proporções sócio-estruturais}

O Monitoramento das mudanças econômicas e sociais é realizado há já mais de três anos, e isso nos permite fazer comparações dinâmicas. Os dados referentes ao triênio 1993-1995 dão a impressão de instabilidade da estrutura social e de acentuadas mudanças na participação relativa dos grupos e das camadas sociais de um ano para outro. Entretanto, os indicadores da estrutura social se referem às características mais fundamentais e mais lentamente mutáveis da sociedade; e os nossos dados, por sua vez, referem-se a não mais do que três anos. Quão real é o surgimento de tão sérias mudanças em um período relativamente curto? Não é fácil responder a essa pergunta simplificadamente. Em favor da probabilidade de mudanças suficientemente rápidas e substanciais da estrutura social, há as particularidades do momento histórico. A Rússia atravessa uma época de rápido transcorrer de acontecimentos, que mudam as características profundas da sociedade gradualmente, mas de passagem "total" forçada de um estado qualitativo para outro. Os mecanismos sociais dessa passagem são a reforma das relações sociais, a adaptação, em múltiplos planos, dos grupos e camadas sociais às 
condições mutantes de vida e, correspondentemente, à intensa mobilidade social. Em tais condições, a contração de alguns grupos, a mudança das qualidades sociais de outros, o surgimento e a ampliação de terceiros representam um fenômeno normal.

Tal é a resposta à pergunta feita acima, a partir da realidade social. Quanto à precisão e à fidedignidade da medição dos grupos e camadas sociais, podemos indicar, no mínimo, três fontes de erros potenciais. A primeira está relacionada a falhas no planejamento e realização da amostra do Monitoramento; a segunda, à identidade incompleta dos indicadores de status nos questionários, e a terceira ao uso de indicadores indiretos do status, devido à falta de dados diretos. Isso nos permite falar antes de tendências qualitativas, que quantitativas na transformação da estrutura social.

Os cálculos correspondentes mostram que, durante o período estudado, alguns grupos sociais se ampliaram substancialmente, outros permaneceram mais ou menos estáveis, e terceiros reduziram-se sensivelmente. Se ordenarmos esses grupos segundo o ritmo e o caráter da mudança de seu número, teremos o seguinte quadro:

- aumentou acentuadamente o número de especialistas prósperos $(+103 \%)$, da elite dos trabalhadores $(+55 \%)$, dos médios e grandes empresários $(+40 \%)$ e dos semi-empresários $(+25 \%)$;

- embora em menor grau, mas também sensivelmente, aumentou o número de militares $(+21 \%)$, semi-inteligentsia $(+18 \%)$, pequenos empresários $(+14 \%)$ e trabalhadores do comércio e dos serviços $(+10 \%)$;

- quase na mesma proporção, diminuiu o número de camponeses (-16\%), de operários não-qualificados (-17\%), da massa da inteligentsia (especialistas) $(-19 \%)$ e de trabalhadores da indústria $(-21 \%)$;

- diminuiu muito fortemente o número de gerentes nas esferas produtiva $(-30 \%)$ e não-produtiva $(-52 \%)$.

Substancialmente, temos diante de nós um quadro de transformação da estrutura sócio-profissional na direção do mercado. É visível o crescimento do número de dois tipos de grupos. O primeiro reúne os portadores diretos do "princípio de mercado", a saber: os grandes, médios e pequenos empresários, os semi-empresários, os trabalhadores do comércio e dos serviços. Ao segundo pertencem os grupos possuidores de qualificação profissional deficitária no mercado de trabalho (especialistas qualificados, a elite dos operários e trabalhadores da estrutura de coerção). A força de trabalho desse tipo tem muita procura e é bem paga, o que facilita a adaptação dos trabalhadores às novas condições e o recrutamento dos representantes dos grupos conexos.

Os "grupos-doadores" também se dividem em dois subgrupos. O primeiro é representado por trabalhadores ocupados em atividade industrial e tradicional, 
de desenvolvimento técnico-científico ultrapassado pelos países mais avançados. São os trabalhadores industriais, os camponeses e os trabalhadores não-qualificados. Em condições de queda geral da produção, de paralisação de muitos setores e oficinas e de enorme desemprego disfarçado, a situação desses trabalhadores é a menos estável. Uns aposentam-se prematuramente ou passam a dedicar-se ao lote de exploração econômica complementar (característica da organização kolkhoziana [N.T.]); outros aceitam qualquer trabalho que possam fazer (inclusive o comércio de rua ou de outro tipo), enquanto terceiros engrossam as fileiras dos desempregados. Os jovens, vendo o destino pouco atraente dos velhos, evitam essas profissões sem perspectivas. Por isso o fator tempo e a mudança de gerações contribuem para a redução de tais grupos.

A questão é distinta no tocante à massa da inteligentsia, aos dirigentes da produção e aos administradores da esfera não-produtiva. O principal fator da redução do seu número é a contração do trabalho resultante da paralisação das empresas estatais e da destruição da infra-estrutura social. A sociedade soviética orgulhava-se de ter "a maior massa de inteligentsia do mundo" - engenheiros, médicos, professores, agrônomos. Para a gestão desse exército também exigia-se uma quantidade não-pequena de administradores. A passagem para o mercado provocou a decadência da infra-estrutura social, que funcionava em bases paternalistas. Contraiu-se o sistema de escolas médias, desmoronou a assistência médica de massa, desapareceu o desenvolvido sistema de sanatórios, campos de pioneiros, instituições para crianças em idade pré-escolar, ambulatórios profiláticos, colônias de férias e casas de repouso. Simultaneamente, da esfera produtiva e dos institutos de pesquisa científica reestruturados ou liquidados foi liberada uma grande massa de especialistas, obrigados a procurar nova aplicação para suas habilidades. Nem todos o conseguiram, o que é atestado pelo aumento do desemprego. No entanto, parte dos especialistas dedicou-se à atividade empresarial, eventualmente conciliada com o trabalho assalariado. Outra parte deles, depois de elevar a sua qualificação e intensificar o seu trabalho, logrou encontrar outro lugar na sociedade, engrossando as fileiras dos especialistas prósperos. Já uma terceira parte teve de restringir-se a trabalho mais ou menos bem pago de ajudantes de especialistas (semi-inteligentsia). Processos análogos ocorreram também na esfera do trabalho predominantemente físico.

Tudo que foi dito revela a profundidade e a natureza contraditória do processo de transformações experimentado pela Rússia. Elementos de modernização conjugam-se com retrocesso social, não sendo fácil definir qual dessas tendências predomina. Em seu todo, as reformas deram impulso antes ao progresso do que à degradação da sociedade, mas as mudanças positivas abrem caminho por entre os espinhos das mudanças negativas. Lugar central ocupa agora o problema da adaptação dos grupos massivos à nova realidade social. Como demostram as pesquisas, nos primeiros anos das reformas radicais (1992-1993), a proporção das pessoas adaptadas às novas condições aumentou. Em seguida, porém, ela se estabilizou e, mais recentemente, começou a diminuir, o que evidencia o esgotamento dos recursos de adaptação da sociedade. Em 1993, a relação 
entre as pessoas, que achavam que "as coisas na Rússia iam na direção certa" e as que achavam que "os acontecimentos conduzem a Rússia para um beco sem saída" era 3: 4, isto é, era mais ou menos equilibrada; hoje, para cada resposta positiva, há mais de cinco respostas negativas. Se pudessem escolher, três quintos dos russos desejariam voltar ao período "de estagnação" (assim denominado o período da gestão Bréjnev [N.T.]); apenas um sexto preferiria a vida atual. A indiferença da burocracia dirigente às necessidades do cidadão comum ameaça conduzir a conflitos políticos e a tentativas de restauração do sistema soviético, socialmente desprovido de perspectivas. Nessas condições, o dever da Ciência é avaliar objetivamente os resultados econômicos e sociais do processo de transformação em curso na Rússia, o grau da sua correspondência aos interesses dos grupos e das camadas sociais massivos, os caminhos e as possibilidades da sua adaptação ao mercado. Os cientistas poderiam, com isso, contribuir para a elaboração de uma estratégia para tirar o país da crise.

Notas

1 Ver, por exemplo, M. Maliutin. Novaia' elita v novoi Rossii. (A nova elite na nova Rússia). Jurnal Obshestvenye Nauki i Sovremenost (Revista Ciências Sociais e Contemporaneidade), 1992, (2); E. Avraamova, I. Dískin. "Sotsial'nye transformatsii i elity" (As transformações sociais e as elites). Jurnal Obshestvenye Nauki i Sovremenost. 1994, (3); B.V. Golovatchov, L.B. Kossova, L.A. Khakhúlina. Formirovanie praviashei elity v Rossii. VTSIOM. Economitcheskie i Sotsial'nye Peremeny: Monitoring Obshestpenovo Mnenia. (CRPOP. A formação da elite dirigente na Rússia. Mudanças econômicas e sociais. Monitoramento da opinião pública). 1996, l (21), p. 32-38.

2 Mais pormenores em: T. I. Zaslávskaia, R. V. Ryvkina. Sotsiolognia economitcheskoi gizni. (Sociologia da vida econômica). Novossibirsk, Naúka, 1991, p. 426-427.

3 Ver, por exemplo, L. A. Beliáeva (org.). Sotsial'naia stratifikatsia sovremenovo rossiiskovo obshestra. (A estratificação social da sociedade russa contemporânea). In: Gueneralni proiekt "Rossia v tretém tyciatchelenii". Seria: Sotsiologuia (Projeto geral "A Rússia no terceiro milênio"). Série: Sociologia. Fascículo XIII, Moscou, 1995; Perspectivy rasvitia srednevo classa v Rossii. (As perspectivas de desenvolvimento da classe média na Rússia. In: Sotsiolognitcheski Jurnal (Revista de Sociologia), Moscou, 1992, (2); V.V. Radaev. Dva cornia rossiiskovo predprinimatels'tva: fragmenty istorii. (As duas raízes da atividade empresarial russa: fragmentos da história). In: Mir Rossii. (O Mundo da Rússia), v. IV, 1995 , I (5), p. 159-180; M. Moguilner. Rosiiskaia radical'naia inteligentsia pered litsom smerti. (A inteligentsia russa radical em face da morte). Jurnal Obshestpenye Nauki i Sovremenost, (5), 1994.

4 Por exemplo, o CRPOP e o Intertsentr dispõem dos dados da pesquisa internacional "Estratificação social nos países da Europa Oriental depois de 1989", realizada em 1993 na Bulgária, Hungria, Polônia, Rússia, República Eslovaca e República Tcheca, sob a direção dos professores D. Treiman e I. Seleni, da Universidade da Califórnia, Los Angeles. Em cada país, inclusive na Rússia, a pesquisa foi feita com base em um 
grupo representativo de cinco mil pessoas. Além disso, foram entrevistados de $500 \mathrm{a}$ 1.000 representantes das velha e nova elites.

5 No presente artigo, expõem-se os resultados do trabalho relativo às duas primeiras.

6 Além das avaliações dos status parciais e totais dos grupos, a hipótese teórica sobre a estrutura social contém descrições preliminares das funções sociais de cada grupo social, das características sociais correspondentes a tais funções, da composição aproximada, por qualificação profissional e função, da estrutura interna (subgrupos mais importantes), bem como das particularidades dos status dos grupos no período de transição. A elaboração teórica preliminar desse amplo leque de questões ajudou-nos muito na identificação empírica dos grupos, mas a exposição desses elementos da hipótese não nos parece oportuna neste artigo .

7 O método utilizado nos cálculos correspondentes está descrito nos artigos: T. I. Zaslávskaia. Dokhody rabotaiushevo nacelenia Rossii (As rendas da população trabalhadora da Rússia). Tchast 1: Sotsial'naia shcala material'noi obespetchenosti. (Parte I: A escala social da abastança material). Tchast 2: Uroven, dinamica i diferentsiatsia (Parte II: Nível, dinâmica e diferenciação). In: VTSIOM Economitcheskie $i$ Sotsial'nye Peremeny v Rossii. Monitoring Obshestvenovo Mnenia , 1994, (1), p. 3 -10, (2), p. 5-12.

8 T.I. Zaslávskaia. Bizness-sloi rossiiscovo obshestva: poniatie, structura, identificatsia. (A camada dos homens de negócios da sociedade russa: conceito, estrutura, identificação). In: VTSIOM Economitcheskie i Sotsial'nye Peremeny v Rossii, 1994, (5), p. 7-15; T. I. Zaslávskaia. O bizness-sloe rossiiscovo obshestva. (Sobre a camada dos homens de negócios da sociedade russa). In: Jurnal Obshestvenye Nauki i Sovremenost, 1995, (1).

9 Uma das razões disso é, sem dúvida, o pequeno número dos grupos citados, os quais compõem menos de $1 \%$ da população economicamente ativa. Não obstante, de acordo com a lei dos grandes números, os dados do monitoramento deveriam incluir cerca de 100 representantes da elite. Destes, no entanto, só foram incluídos menos de uma dezena, já que as top-persons russas geralmente se esquivam de pesquisas.

10 V. T. I. Zaslávskaia. Sotsial'naia structura sovremenovo rossiiscovo obshestva (A estrutura da sociedade russa contemporânea). In: VTSIOM Economitcheskie Sotsial'nye $i$ Peremeny v Rossii. Monitoring Obshestvenovo Mnenia, 1995, (6), p. 7-13.

$11 \mathrm{O}$ índice de urbanização das povoações por nós calculado pode assumir valores de 0,125 (se todos os representantes da camada vivem em aldeias) a l (se todos vivem em capital).

12 T. I. Zaslávskaia. Real'nye dokhody rossian tcherez prismu sotsial'nikh otsenoc. (A renda efetiva dos russos pelo prisma das avaliações sociais.) In: Óbschestvo i Ekonómika (Sociedade e Economia), 1994, (3-4), p. 50.

13 VTSIOM Economitsheskie i Sotsial'nye Peremeny v Rossii. Monitoring Obshestvenovo Mnenia, 1996, (1), p. 57.

14 Calculado com base nos dados do anuário Naródnoe Khoziáistvo SSSR v 1988 godu (A economia da URSS no ano de 1988), Moscou, Finansi i Statístika, 1989, p. 93. 
15 L. G. Zúbova. Sotsial'noe rasloenie: pologenie "poliarnikh" grup nacelenia. (Estratificação social: a situação dos grupos "polares" da população). In: VTSIOM Economitsheskie I Sotsial'nyie Peremeny v Rossii, 1996, (1), p. 40.

16 L. G. Zúbova. Otsenki diferentsiatsii dokhodov (Avaliações da diferenciação da renda). In: VTSIOM Economitsheskie i Sotsial'nye peremeny v Rossii. Monitoring Obshestvenovo Mnenia, 1996, (6), p. 29.

17 M. A. Mójina. Uroven gizni: diferentsiatsia i bednost. (Nível de vida: diferenciação e pobreza). In: Kuda idiot Rossia? Alternativy obshestpenovo razvitia. (Para onde vai a Rússia? Alternativas do desenvolvimento social). Moscou, Aspekt-press, 1995, p. 155.

18 L. G. Zúbova, N.V. Kovaliova. Potrebitelskii rynok i blagosostoianie (po resul'tatam massovikh oprossov). (Mercado consumidor e bem-estar - com base no resultado de pesquisas de massas). In: Kuda idiot Rossia? Alternativy obshestvenovo razvitia. Moscou, Aspekt-press, 1995, p. 164.

19 Ver, por exemplo, D.S. Lvov. Rossiiskie reformy v global'nom contekste. Doclad na zacedanii presiduma Ran (As reformas russas no contexto global. Relatório apresentado à sessão do Presidium da Academia de Ciências da Rússia em 14 de maio de 1996). In: Nova i Noveishaia Istoria (Nova e Novissima História). 1996, (4), p. 193-214.

20 L. D. Gudkóv, M. V. Ptchólkina. Bednost i zavist: negativnyi fon perekhodnovo obshestva. (Pobreza e inveja: o fundo negativo da sociedade de transição). In: VTSIOM Economitcheskie i Sotsial'nye Peremeny v Rossii. Monitoring Obshestvenoro Mnenia, 1995, (6), p. 31-42.

Tatiana I. Zaslávskai é doutora em ciências econômicas, co-presidente do Centro Acadêmico Interdisciplinar de Ciências Sociais, presidente do Conselho Editorial de Economitcheskie i Sotsial'nye Peremeny v Rossii. Monitoring Obshestvenovo Mnenia (Mudanças econômicas e sociais na Rússia. Monitoramento da opinião pública), membro do Conselho Editorial de inúmeros periódicos russos de ciências sociais.

Tradução de Noé Silva. Revisão de Lenina Pomeranz. O original em russo - Sotsial'naia Struktura Sovremenovo Rossiiskovo Ohshestva - encontra-se à disposição do leitor no IEAUSP para eventual consulta.

A pesquisa, da qual resultou o presente artigo, foi realizada com suporte financeiro da Fundação Científica Humanitária Russa (Rossiskii Gumanitarnyi Nautchnyi Fond), projeto número 96-03-04520. 